
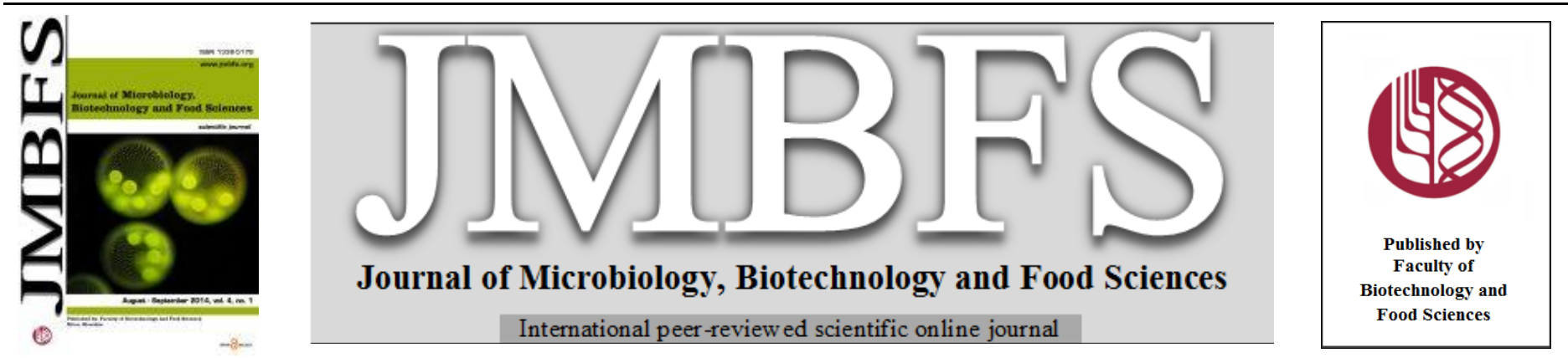

\title{
IN-VITRO BIOREDUCTION OF HEXAVALENT CHROMIUM BY VIABLE WHOLE CELLS OF Arthrobacter sp. SUK 1201
}

\section{Satarupa Dey, A.K. Paul*}

Address(es): Dr. A. K. Paul,

Microbiology Laboratory, Department of Botany, University of Calcutta, 35 Ballygunge Circular Road, Kolkata 700019 , India.

*Corresponding author: amalk_paul@yahoo.co.in

doi: 10.15414/jmbfs.2014.4.1.19-23

\section{ARTICLE INFO}

Received 10. 3. 2014

Revised 4. 6. 2014

Accepted 18. 6. 2014

Published 1. 8. 2014

Regular article

open $O$ access

\section{ABSTRACT}

A chromium resistant and reducing bacterium Arthrobacter sp. SUK 1201 was isolated from chromite mine overburden dumps of Orissa, India. Viable whole cells of this isolate was capable of completely reducing $100 \mu \mathrm{M} \mathrm{Cr}(\mathrm{VI})$ in chemically defined MS medium within $28 \mathrm{~h}$ of incubation under batch cultivation. Reduction of chromate increased with increased cell density and was maximum at a density of $10^{10}$ cells $/ \mathrm{ml}$, but the reduction potential of the suspended cells decreased with increase in Cr(VI) concentration in the medium. Chromate reducing efficiency was promoted when glycerol and glucose was used as electron donors, while the optimum $\mathrm{pH}$ and temperature of $\mathrm{Cr}(\mathrm{VI})$ reduction was found to be 7.0 and $35^{\circ} \mathrm{C}$ respectively. The reduction process was inhibited by divalent cations $\mathrm{Ni}$, Co and $\mathrm{Cd}$, but not by $\mathrm{Cu}$ and $\mathrm{Fe}$. Similarly, carbonyl cyanide $m$-chlorophenylhydrazone (CCCP), N,N,-Di cyclohexyl carboiimide (DCC), sodium azide and sodium fluoride were inhibitory to chromate reduction, while in presence of 2,4 dinitrophenol (2,4 DNP) chromate reduction by SUK 1201 cells remained unaffected.

Keywords: Arthrobacter sp., chromate reduction, chromite mine overburden, bioreduction, bioremediation

\section{INTRODUCTION}

In nature, the transition metal chromium is found to occur as trivalent [Cr(III)] and hexavalent $[\mathrm{Cr}(\mathrm{VI})]$ forms as they represent the most stable oxidation states. Mobilization of $\mathrm{Cr}(\mathrm{III})$ is slow unless dissolved in acidic environment or complexed with organic compounds (Rai et al., 1987) and is less bioavailable in natural environment, whereas $\mathrm{Cr}(\mathrm{VI})$ is highly toxic, carcinogenic and mutagenic (Bagchi et al., 2002) due to its high degree of solubility and membrane permeability leading to oxidative stress, DNA damage and altered gene expression.

Reduction of toxic $\mathrm{Cr}(\mathrm{VI})$ to less toxic $\mathrm{Cr}(\mathrm{III})$ from and its subsequent precipitation at neutral $\mathrm{pH}$ is one of the cost-effective and eco-friendly method for detoxification of $\mathrm{Cr}(\mathrm{VI})$ in contaminated wastes. On the contrary, the traditional physico-chemical processes of detoxification such as precipitation, ion exchange and adsorption are not only expensive but also generate secondary pollutants (Camargo et al., 2003). Pure cultures of a wide variety of bacteria strains (Camargo et al., 2003; Asianti et al., 2004) as well as consortium (Molokwane et al., 2008) have been reported to reduce $\mathrm{Cr}(\mathrm{VI})$ under both aerobic (Megharaj et al., 2003; Thacker et al., 2007) and anaerobic conditions (Cervantes et al., 2001). In addition, chromium resistant and reducing bacteria isolated from chromite mining environments have attracted increased interest for potential application in bioremediation of $\mathrm{Cr}(\mathrm{VI})$ polluted waste water (Dhal $\boldsymbol{e}$ t al., 2010; Dey and Paul, 2012). Arthrobacter, the common Gram-positive bacteria having characteristics rod to cocci cell cycle are capable of surviving in various chromium contaminated industrial areas such as tannery (Meghraj et al., 2003), chromite mine (Molokwane et al., 2008; Dey and Paul, 2012) and Department of Energy (DOE) waste sites (Asianti et al., 2004) and have been explored for their chromate reducing potentials. These isolates were able to reduce hexavalent chromium during growth, by whole cells and also by cell-free extracts. Asianti et al., (2004) and Meghraj et al., (2003) have demonstrated that Arthrobacter strains were able to reduce nearly 35 and $30 \mu \mathrm{g} / \mathrm{ml}$ of $\mathrm{Cr}$ (VI) in 10 day and 46 h respectively. Similarly, Camargo et al., (2004) have evaluated the chromate reducing efficiency of Arthrobacter crystallopoites ES 32 during growth.

During the course of screening of bacterial strains capable of reducing hexavalent chromium, we have reported the isolation of Arthrobacter sp. SUK 1201 from chromite mine overburdens of Orissa, India and have evaluated its chromate reducing potential during growth (Dey and Paul, 2012). The present study concentrates on the assessment of $\mathrm{Cr}(\mathrm{VI})$ reduction ability of the viable whole cells of Arthrobacter sp. SUK 1201 under batch culture and determination of optimum conditions for such reductions.

\section{MATERIAL AND METHODS}

\section{Source and maintenance of bacterial culture}

The chromate reducing bacterium, Arthrobacter sp. SUK 1201 (MTCC accession number 8728 and NCBI Gen Bank accession No. JQ312665) used in this study was isolated from mine overburden materials collected from Sukinda chromite mining areas of Orissa, India (Dey and Paul, 2012). The strain was routinely maintained on slopes of peptone, yeast extract and glucose (PYEG) agar medium (Wang and Xiao, 1995) containing (g/L) peptone, 10.0; yeast extract, 5.0; glucose, 3.0 and agar agar, 20.0 (pH 7.0). The medium was supplemented with 2 $\mathrm{mM} \mathrm{Cr}(\mathrm{VI})$ and the over-night grown cultures were stored at $4^{\circ} \mathrm{C}$ for short term preservation, while for long-term preservation, the freshly grown cells were suspended in sterile $30 \%$ glycerol in cryo vials and stored at $-80^{\circ} \mathrm{C}$ for future use.

\section{Preparation of cell mass for chromate reduction studies}

Whole cells of Arthrobacter sp. SUK 1201 were harvested from overnight grown cultures incubated at $35^{\circ} \mathrm{C}$ under continuous shaking in MS medium. The MS medium contained (g/L): $\mathrm{NH}_{4} \mathrm{Cl}, 0.03 ; \mathrm{K}_{2} \mathrm{HPO}_{4}, 0.03 ; \mathrm{KH}_{2} \mathrm{PO}_{4}, 0.05 ; \mathrm{NaCl}, 0.01$ $\mathrm{MgSO}_{4}, 7 \mathrm{H}_{2} \mathrm{O}, 0.01(\mathrm{pH}$ 7.0). The cell mass was obtained by centrifugation $(10,000 \times g)$ at $4^{\circ} \mathrm{C}$ for 10 min and washed 2-3 times with ice cold Tris buffer ( $\mathrm{pH}$ 7.2) following the method of Wang and Xiao (1995). The cell mass thus obtained was diluted to a particular cell density and used for reduction studies. Viability of the cells was determined by serial dilution of the cell suspension and plating on PYEG agar medium supplemented with $2 \mathrm{mM} \mathrm{Cr}(\mathrm{VI})$. Viable cell numbers $/ \mathrm{mL}$ were calculated from the colony forming units (c.f.u)/mL after $24 \mathrm{~h}$ of incubation at $35^{\circ} \mathrm{C}$.

\section{Chromate reduction by suspended whole cells}

Chromate reduction by viable whole cells of Arthrobacter sp. SUK 1201 was carried out in $25 \mathrm{~mL}$ of Minimal salts (MS) medium (in $100 \mathrm{~mL}$ Erlenmeyer flasks) supplemented with $100 \mu \mathrm{M}$ Cr(VI). Flasks were inoculated with viable cells at a density of $10^{8}$ cells $/ \mathrm{mL}$ and incubated at $35^{\circ} \mathrm{C}$ under continuous shaking $(120 \mathrm{rpm})$ in a rotary shaker. Samples were withdrawn aseptically at regular 
intervals and reduction of chromate was estimated by measuring the residual hexavalent chromium in the reduction medium using diphenylcarbazide method (Park et al., 2000). The growth of the cells was determined by counting tota number of cells/mL of culture using a haemocytometer (Neubauer, Fein-Optik Jena, Germany) and a phase contrast microscope (Zeiss Winkel Model no. 148786, Germany).

\section{Effect of different media on chromate reduction}

Effect of different media on chromate reduction capability of viable whole cells of Arthrobacter sp. SUK 1201 was determined using mineral salts (MS) medium, half-strength peptone yeast extract glucose (PYEG) medium and Vogel Bonne (V. B.) broth. The half-strength PYEG medium was prepared by diluting the PYEG medium with distilled water in the ratio of $1: 1$. Vogel Bonner broth was made up of $2.0 \%$ sterile stock solution of $\mathrm{V}$. B. concentrate. The V. B concentrate contained (g/L): $\mathrm{K}_{2} \mathrm{HPO}_{4}, 500.0 ; \mathrm{Na}\left(\mathrm{NH}_{4}\right) \mathrm{HPO}_{4} .4 \mathrm{H}_{2} \mathrm{O}, 175.0$; citric acid, $100.0 ; \mathrm{MgSO}_{4} .7 \mathrm{H}_{2} \mathrm{O}, 10.0$ and $2.0 \%$ of $25 \%$ D-glucose $(\mathrm{pH} 7.0)$ (Wang and Xiao, 1995). The media were supplemented with $100 \mu \mathrm{M} \mathrm{Cr}(\mathrm{VI})$ using separately sterilized chromate solution and inoculated with viable cells at a density of $10^{8}$ cells $/ \mathrm{mL}$. Conditions of growth, measurement of growth and residual hexavalent chromium in the reduction medium were same as described earlier.

\section{Effect of electron donors on chromate reduction}

Chromate reduction by viable whole cells of Arthrobacter sp. SUK 1201 was studied in presence of various electron donors, which include glycerol, glucose, sucrose, acetate, citrate, propionate, glycine, peptone, tryptone and yeast extract. The reduction medium $(25 \mathrm{~mL}$ of $\mathrm{MS}$ medium/100 $\mathrm{mL}$ ) was supplemented with $100 \mu \mathrm{M} \mathrm{Cr}(\mathrm{VI})$ along with the electron donors at $0.1 \%(\mathrm{w} / \mathrm{v})$. Other experimental conditions were same as described above.

\section{Effect of $\mathrm{pH}$ on chromate reduction}

Effect of different $\mathrm{pH}$ on the $\mathrm{Cr}(\mathrm{VI})$ reducing capability of whole cells of Arthrobacter sp. SUK 1201 was determined by adjusting the $\mathrm{pH}$ of Minimal salts (MS) medium in the range of $\mathrm{pH} 4-8$ using $0.1(\mathrm{~N}) \mathrm{NaOH}$ and $0.1(\mathrm{~N}) \mathrm{HCl}$ Chromate concentration, cell density/mL and incubation conditions were same as described earlier.

\section{Effect of additional metal ions on chromate reduction}

Chromate reduction by Arthrobacter sp. SUK 1201 was studied in presence of additional metal ions such as $\mathrm{Mn}(\mathrm{II}), \mathrm{Co}(\mathrm{II}), \mathrm{Zn}(\mathrm{II}), \mathrm{Fe}(\mathrm{III}), \mathrm{Cu}(\mathrm{II}), \mathrm{Ni}$ (II) and $\mathrm{Cd}(\mathrm{II})$. The metals were used as chloride salts, sterilized separately and added to MS medium at equimolar $(100 \mu \mathrm{M})$ level of $\mathrm{Cr}(\mathrm{VI})$. Other experimental conditions were same as described above.

\section{Effect of metabolic inhibitors on chromate reduction}

The effect of metabolic inhibitors on chromate reduction by viable whole cells of Arthrobacter sp. SUK 1201 was investigated using the protonophore carbonyl cyanide $m$-chlorophenylhydrazone (CCCP), ATPase inhibitor N,N,-Di cyclohexyl carboiimide (DCC), artificial electron acceptor sodium azide, enolase inhibitor sodium fluoride and 2,4 dinitrophenol (2,4 DNP). The inhibitors were separately sterilized and added to the reduction medium at equimolar concentration.

\section{Statistical analysis}

All experiments were carried out in triplicate and results represent mean \pm standard error.

\section{RESULTS}

\section{Effect of different media on chromate reduction}

Freshly grown viable cells of Arthrobacter sp. SUK 1201 were used to determine the effect of different media on chromate reduction. The test media include mineral salts (MS) medium, half strength peptone yeast extract glucose (PYEG) medium and Vogel Bonner (V. B.) broth. Results indicate that whole cells of Arthrobacter sp. SUK 1201 in half strength PYEG medium was the most effective one as complete reduction of initial $\mathrm{Cr}(\mathrm{VI})$ occurred in $16 \mathrm{~h}$. This was followed by MS medium, where complete reduction of $100 \mu \mathrm{M} \mathrm{Cr}(\mathrm{VI})$ was achieved within $28 \mathrm{~h}$. However, in V. B. broth nearly $79 \%$ of $\mathrm{Cr}(\mathrm{VI})$ was reduced by cells of SUK 1201 (Figure 1). Considering the efficacy of reduction as well as to avoid chances of interference of the organic constituents of PYEG medium in the process of reduction, the MS medium was selected and used as the base for subsequent chromate reduction studies with whole cells of Arthrobacter sp. SUK 1201.

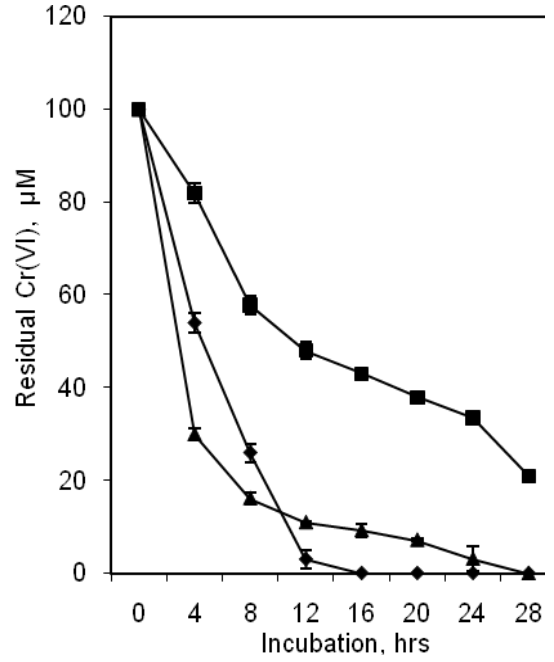

Figure 1 Effect of different media on hexavalent chromium reduction by whole cells of Arthrobacter sp. SUK 1201 (- - PYEG medium, - - - V.B. broth and $\Delta$ - MS medium)

\section{Effect of cell density}

Chromate reducing capacity of the whole cells of the isolate SUK 1201 was tested at a cell density of $10^{8}-10^{10}$ cells/mLin MS medium. Results as represented in Figure 2 clearly indicate that $10^{10}$ cells $/ \mathrm{mLw}$ was the level of cell concentration where complete reduction of chromate occurred within $16 \mathrm{~h}$ of incubation. However, whole cells at a density of $10^{8}$ cells $/ \mathrm{mL}$ were comparatively less efficient in reducing the chromate and require prolong incubation for equivalent reduction.

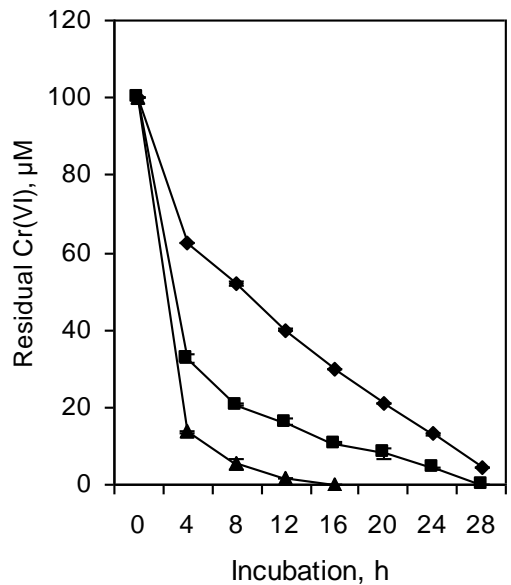

Figure 2 Hexavalent chromium reduction by whole cells of Arthrobacter sp SUK 1201 as influenced by cell density $\left(--10^{8},-\mathbf{\square}-10^{9},-\boldsymbol{\Delta}-10^{10}\right.$ cells $\left./ \mathrm{mL}\right)$

\section{Effect of $\mathrm{Cr}$ (VI) concentration}

Chromate reducing capacity of the whole cells of isolate SUK 1201 was evaluated at $\mathrm{Cr}(\mathrm{VI})$ concentrations ranging from 50-600 $\mu \mathrm{M}$. Reduction efficiency of Arthrobacter sp. SUK 1201 cells was found to increase with increase in $\mathrm{Cr}(\mathrm{VI})$ concentration up to $100 \mu \mathrm{M}$. Although complete reduction of 50 and $100 \mu \mathrm{M} \mathrm{Cr}(\mathrm{VI})$ occurred within 16 and $28 \mathrm{~h}$ respectively, nearly 89,82 and $58 \%$ of initial chromium was reduced in $28 \mathrm{~h}$ when the initial chromium concentration of the reduction medium was maintained at 200, 400 and $600 \mu \mathrm{M}$ respectively (Figure 3). 


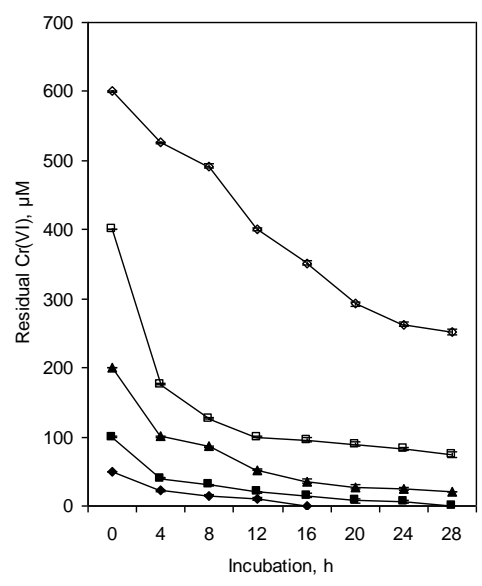

Figure 3 Hexavalent chromium reduction by whole cells of Arthrobacter sp SUK 1201 as influenced by $\mathrm{Cr}(\mathrm{VI})$ concentration $(-\boldsymbol{-}$ - 50, - $\mathbf{-}-100,-\boldsymbol{\Delta}-200$, - $\square-$ $400,-\diamond-600 \mu \mathrm{M})$

\section{Effect of electron donor}

Chromate reduction by whole cells of Arthrobacter sp. SUK 1201 was studied in presence of various electron donors $(0.1 \% \mathrm{w} / \mathrm{v})$. The electron donors include glycerol, glucose, sucrose, acetate, citrate, propionate, glycine, peptone, tryptone and yeast extract. Results as demonstrated in Figure 4 clearly indicate that $\mathrm{Cr}(\mathrm{VI})$ reduction was very much dependent on the electron donor present in the medium. Maximum $\mathrm{Cr}(\mathrm{VI})$ reduction was evident when glycerol, glucose and peptone was used as the electron donor. In presence of these electron donors, complete reduction of $\mathrm{Cr}(\mathrm{VI})$ occurred. Propionate was found to be least efficient as electron donor for chromate reduction by SUK 1201 cells.

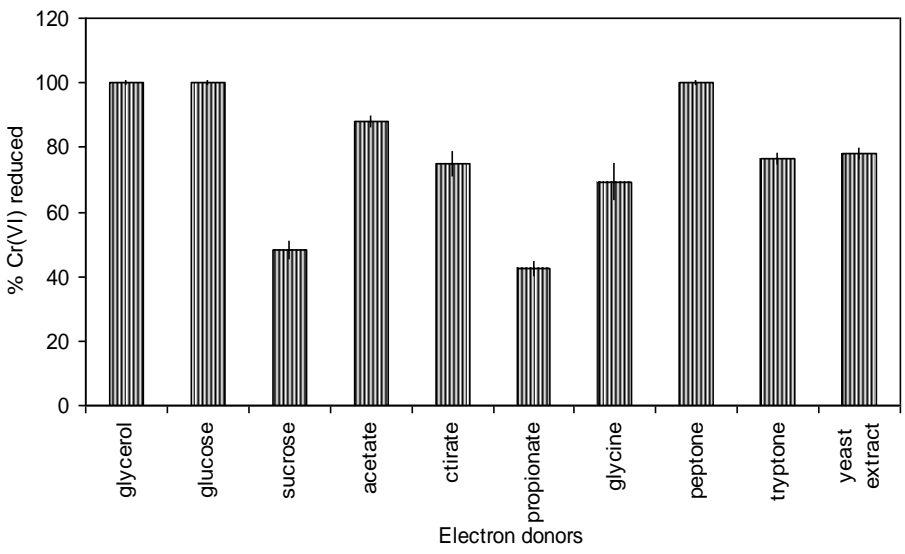

Figure 4 Effect of electron donor on $\mathrm{Cr}(\mathrm{VI})$ reduction by whole cells of Arthrobacter sp. SUK 1201

\section{Effect of $\mathbf{p H}$}

Effect of $\mathrm{pH}$ on chromate reduction was carried out in MS medium adjusted to different $\mathrm{pH}$ values. $\mathrm{Cr}(\mathrm{VI})$ reduction by whole cells of Arthrobacter sp. SUK 1201 was greatly dependent on the $\mathrm{pH}$ of the medium. Results show that maximum $\mathrm{Cr}(\mathrm{VI})$ reduction occurred at $\mathrm{pH} 7.0$, which was retarded both by the acidic and alkaline $\mathrm{pH}$ of the medium (Figure 5).

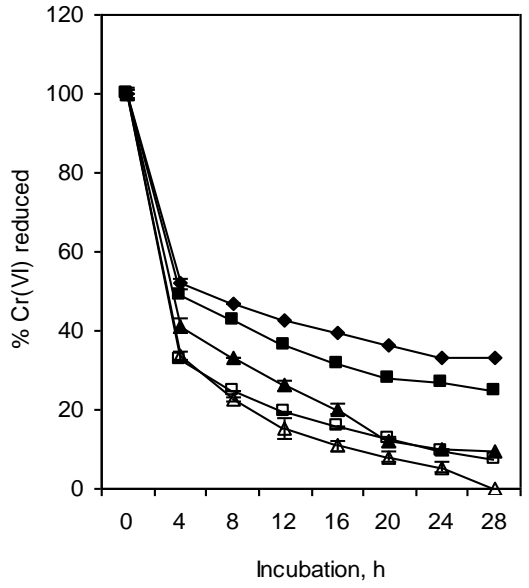

Figure 5 Effect of $\mathrm{pH}$ on $\mathrm{Cr}(\mathrm{VI})$ reduction by whole cells of Arthrobacter sp. SUK $1201(-\uparrow-4.0,-\square-5.0,-\boldsymbol{\Delta}-6.0,-\Delta-7.0,-\square-8.0)$

\section{Effect of additional metal ions}

Chromate reduction by whole cells of the isolate Arthrobacter sp. SUK 1201 showed that supplementation of $\mathrm{Mn}$ (II), $\mathrm{Co}(\mathrm{II}), \mathrm{Zn}$ (II) and $\mathrm{Ni}$ (II) in the MS medium were in general inhibitory to chromate reduction. Mn(II) was most inhibitory showing nearly $42.6 \%$ inhibition of hexavalent chromium reduction when compared with the control. Co(II) showed $36 \%$ inhibition followed by $\mathrm{Zn}$ (II) and $\mathrm{Ni}$ (II) showing 34 and $18 \%$ inhibition respectively. Presence of Fe(III) and $\mathrm{Cu}$ (II) however, appeared to be promotive in nature showing complete reduction of $100 \mu \mathrm{M}$ of $\mathrm{Cr}(\mathrm{VI})$ with $16 \mathrm{~h}$ of incubation (Figure 6).

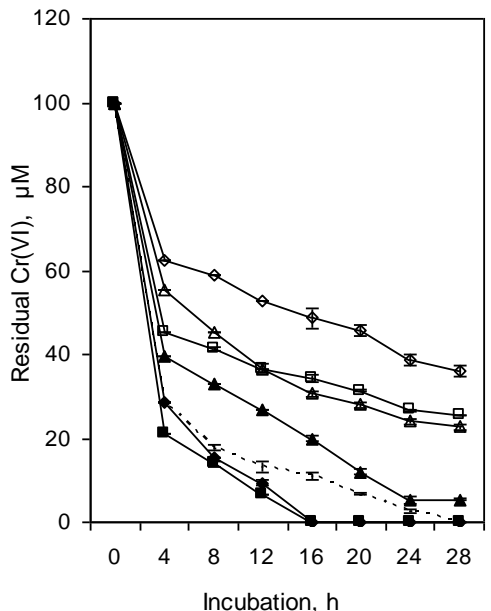

Figure 6 Effect of metal ions on $\mathrm{Cr}(\mathrm{VI})$ reduction by whole cells of Arthrobacter sp. SUK 1201 [Metals: - - Fe(III), - $-\mathrm{Cu}(\mathrm{II}),-\boldsymbol{\Delta}$ - Ni(II), - $\Delta$ - Co(II), - $-\mathrm{Zn}(\mathrm{II})$, $\diamond-\mathrm{Mn}(\mathrm{II}),---$ Control]

\section{Effect of metabolic inhibitors}

Chromate reduction by free whole cells of SUK 1201 was affected by the presence of inhibitors in reduction medium. The response of 2,4-di nitrophenol (2,4 DNP) on chromate reduction by whole cells of SUK 1201 was neither inhibitory nor promotive as the extent of $\mathrm{Cr}(\mathrm{VI})$ reduction in presence of 2,4 DNP was more or less identical with the control. Protonophores like sodium fluoride was the strongest inhibitor causing $42.6 \% \mathrm{Cr}(\mathrm{VI})$ reduction followed by carbonyl cyanide- $m$-chloro phenyl hydrazone (CCCP), sodium azide and $\mathrm{N}, \mathrm{N}$, Dicyclohexyl carboiimide (DCC) (Figure 7) 


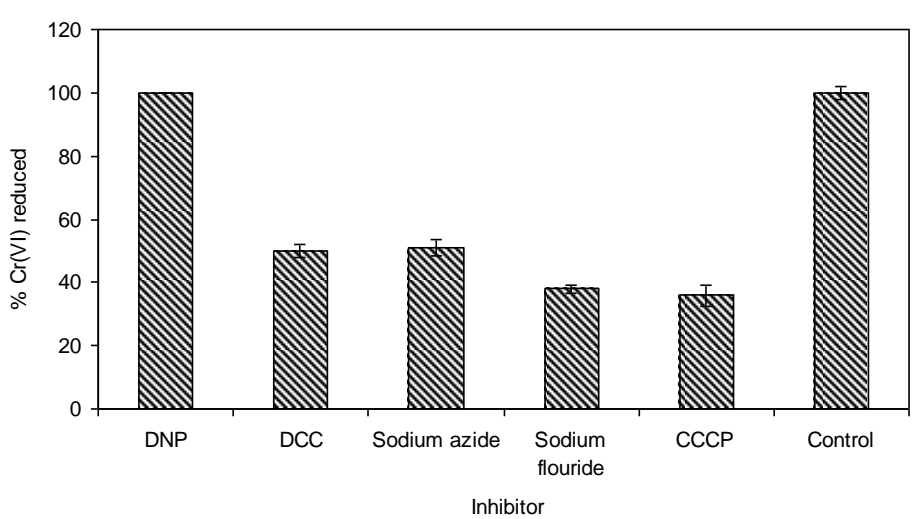

Figure 7 Effect of inhibitors on $\mathrm{Cr}(\mathrm{VI})$ reduction by whole cells of Arthrobacter sp. SUK 1201

\section{DISCUSSION}

Aerobic reduction of hexavalent chromium by viable whole cells in suspended mode have been studied quite extensively using a variety of microorganisms (Farag and Zaki, 2010; Ezaka and Anyanwu, 2011). During the present investigation, chromate reduction by viable whole cells of Arthrobacter sp. SUK 1201 (MTCC accession number 8728 and NCBI Gen Bank accession No. JQ312665) has been studied under batch culture using a chemically defined MS medium.

The composition of the suspending media greatly influenced the efficiency of chromate reduction by SUK 1201 cells under laboratory conditions (Figure 1). The half strength peptone yeast extract glucose (PYEG) medium, though showed complete reduction of chromate but was not considered for further experiments as it is reported to reduce the availability of hexavalent chromium due to its complexation with organic constituents. The minimal salts (MS) medium supplemented with $0.1 \%(\mathrm{w} / \mathrm{v})$ glucose was considered as the most effective one for $\mathrm{Cr}(\mathrm{VI})$ reduction by Arthrobacter sp. SUK 1201. MS medium being a completely inorganic one, minimized the possible complexation of $\mathrm{Cr}(\mathrm{VI})$ with media components and allowed the assessment of $\mathrm{Cr}(\mathrm{VI})$ reduction potential more accurately. Meghraj et al. (2003) in their study also reported similar results with Arthrobacter sp.

A high cell density $\left(10^{10}\right.$ cells $\left./ \mathrm{mL}\right)$ of Arthrobacter sp. SUK 1201 was essentially required for complete reduction of $100 \mu \mathrm{M} \mathrm{Cr}(\mathrm{VI})$ in $16 \mathrm{~h}$ (Figure 2). Simila results were also found with Microbacterium MP 30 (Pattanapipitpaisal et al. 2001), where the rate of $\mathrm{Cr}(\mathrm{VI})$ reduction increased with increase in cell concentration ranging from $10^{7}-10^{10}$ cells $/ \mathrm{mL}$. Likewise, with increase in cell density, the rate of $\mathrm{Cr}(\mathrm{VI})$ reduction was also found to increase in Bacillus sphaericus AND 303 (Pal and Paul, 2004).

The rate of chromate reduction by suspended whole cells of wide variety of bacteria has been reported to be greatly influenced by the initial $\mathrm{Cr}(\mathrm{VI})$ concentration (He et al., 2009; Pattanapipitpaisal et al., 2001; Wang and Xiao, 1995). In the present study complete reduction by the cells of SUK 1201 occurred only when the $\mathrm{Cr}(\mathrm{VI})$ concentration was maintained at 50 and $100 \mu \mathrm{M}$, but at higher concentration complete reduction has failed to occur (Figure 3).

Chromate reducing organisms in general utilize a variety of organic compounds as electron donors for $\mathrm{Cr}(\mathrm{VI})$ reduction. Aerobic $\mathrm{Cr}(\mathrm{VI})$ reduction by whole cells of Pseudomonas sp. (Mc Lean and Beveridge, 2000), Bacillus sp. (Pal and Paul, 2004) and Ochrobactrum sp. (He et al., 2009) has been reported to be enhanced in the presence of glucose. Marbrouk (2008) also reported that peptone and yeast extract favoured chromate reduction in Streptomyces sp. MS-2. Likewise, glycerol, glucose and peptone served as efficient electron donors for Cr(VI) reduction by Arthrobacter sp. SUK 1201 (Figure 4).

The optimum $\mathrm{pH}$ for $\mathrm{Cr}(\mathrm{VI})$ reduction by cells of Arthrobacter sp. SUK 1201 appear to be identical with the optimum $\mathrm{pH}$ for growth of the isolate (Dey and Paul, 2012). Moreover, the process of Cr(VI) reduction by SUK 1201 cells was severely affected by acidic and alkaline pH (Figure 5). Cells of Arthrobacter sp. SUK 1201 effectively reduced chromate in a narrow range of $\mathrm{pH}$ with an optimum of $\mathrm{pH} 7.0$ similar to that of Arthrobacter crystallopoites (Camargo e al., 2003). Such an influence of $\mathrm{pH}$ on the chromate reduction by whole cells of Arthrobacter sp. SUK 1201, may possibly be correlated with their growth as well as metabolic activity. Further, the $\mathrm{pH}$ mediated alteration of the reductase activity may be the result of the modification of the structure or conformation of chromate reductase of Arthrobacter sp. SUK 1201.

Chromium reduction by SUK 1201 cells and its stimulation by $\mathrm{Cu}$ (II) (Figure 6) might be due to the fact that $\mathrm{Cu}$ is a prosthetic group for many reductase enzymes including those of chromium reductases of microbial origin. The copper ions may act as an electron redox center and help in the shuttle of electron between subunits of the enzyme (Sultan and Hasnain, 2006). Similar enhancement of $\mathrm{Cr}(\mathrm{VI})$ reduction potential was also evident with Ochrobactrum intermedium, (Sultan and Hasnain, 2007), Amphibacillus sp. KSUCr3 and Bacillus sp. KSUCr5 (Ibrahim et al., 2011, 2012).
The uncoupler, 2,4 DNP mediated acceleration of chromate reduction by whole cell suspension of Arthrobacter sp. SUK 1201 was supported by enhancement of $\mathrm{Cr}(\mathrm{VI})$ reduction by 2,4 DNP in E. coli (Shen and Wang, 1993), Burkholderia cepacia (Wani et al., 2007) and Staphylococcus gallinarum (Alam and Ahmed, 2011) (Figure 7). On the contrary, sodium azide, CCCP and DCC mediated inhibitory effect on the process of chromate reduction could be due to inhibition of cytochrome oxidase, disruption of chemiosmotic gradient and inhibition of ATPase activity respectively. Similar to Arthrobacter sp. SUK 1201, inhibition of $\mathrm{Cr}(\mathrm{VI})$ reduction in presence of $\mathrm{NaN}_{3}$ was also evident with Stenotrophomonas maltophilia, Staphylococcus gallinarum, Pantoea sp. and Aeromonas sp. (Alam and Ahmed, 2011). Thus optimization of different physico-chemical conditions for $\mathrm{Cr}(\mathrm{VI})$ reduction by viable whole cell suspension of Arthrobacter sp. SUK 1201 establishes its potential for biotechnological application in the transformation of highly toxic and mutagenic $\mathrm{Cr}(\mathrm{VI})$ to less toxic $\mathrm{Cr}(\mathrm{III})$ and thus could be identified as an ideal tool for detoxification of chromium pollutants.

\section{CONCLUSION}

Optimization of conditions for $\mathrm{Cr}(\mathrm{VI})$ reduction by whole cells of Arthrobacter sp. SUK 1201 established its biotechnological potential for transformation of highly toxic and carcinogenic $\mathrm{Cr}(\mathrm{VI})$ to less toxic and insoluble $\mathrm{Cr}$ (III) and thus could be an effective tool in bioremediation of chromium pollutants.

Acknowledgments: Financial support received from the Department of Biotechnology, Ministry of Science and Technology, Government of India vide Sanction number BT/PR/5766/NDB/51/061/2005 is duly acknowledged by the authors.

\section{REFERENCES}

ALAM, M.Z., AHMAD, S. 2012. Toxic chromate reduction by resistant and sensitive bacteria isolated from tannery effluent contaminated soil. Annals of Microbiology, 62, 113-121. http://dx.doi.org/10.1007/s13213-011-0235-4

ASATIANI, N.V., ABULADZE, M.K., KARTVELISHVILI, T.M., BAKRADZE, N.G., SAPOJNIKOVA, N.A., TSIBAKHASHVILI, N.Y., TABATADZE, L.V., ASANISHVILI, L.L., HOLMAN, H. 2004. Effect of chromium (VI) action on Arthrobacter oxydans. Current Microbiology, 49, 321 326. http://dx.doi.org/10.1007/s00284-004-4351-2

BAGCHI, D., STOHS, S.J., BERNARD, W.D., BAGCHI, M., PREUSS, H.G 2002. Cytotoxicity and oxidative mechanism of different forms of chromium. Toxicology, 180, 5-22. http://dx.doi.org/10.1016/s0300-483x(02)00708-4

CAMARGO, F.A.O., OKEKE, B.C., BENTO, F.M., FRANKENBERGER, W.T. 2003. In vitro reduction of hexavalent chromium by a cell-free extract of Bacillus sp. ES 29 stimulated by $\mathrm{Cu}^{2+}$. Applied Microbiology and Biotechnology, 62, 569573. http://dx.doi.org/10.1007/s00253-003-1291-X

CAMARGO, F.A.O., BENTO, F.M., OKEKE, B.C., FRANKENBERGER, W.T. 2004. Hexavalent chromium reduction by an actinomycetes, Arthrobacter crystallopoites ES 32. Biological Trace Element Research, 97, 183-194. http://dx.doi.org/10.1385/bter:97:2:183

CERVANTES, C., CAMPOS-GARCIA, J., DEVARS, S., CORONA, F.G., LOZA-TAVERA, H., CARLOS, J., GUZMAN, T., SANCHEZ, R.M. 2001. Interactions of chromium with microorganisms and plants. FEMS Microbiology Review, 25, 335-347. http://dx.doi.org/10.1111/j.1574-6976.2001.tb00581.x

DEY, S., PAUL, A.K. 2012. Optimization of cultural conditions for growth associated chromate reduction by Arthrobacter sp. SUK 1201 isolated from chromite mine overburden. Journal of Hazardous Material, 213-214, 200-206. http://dx.doi.org/10.1016/j.jhazmat.2012.01.078

DHAL, B., THATOI, H., DAS, N., PANDEY, B.D. 2010. Reduction of hexavalent chromium by Bacillus sp. isolated from chromite mine soils and characterization of reduced product. Journal of Chemical Technology and Biotechnology, 85, 1471-1479. http://dx.doi.org/10.1002/jctb.2451

EZAKA, E., ANYANWU, C.U. 2011. Chromium (VI) tolerance of bacterial strains isolated from sewage oxidation ditch. International Journal of Environmental Science, 1, 1725-1734.

FARAG, S., ZAKI, S. 2010. Identification of bacterial strains from tannery effluent and reduction of hexavalent chromium. Journal of Environmental Biology, 31, 877-882.

HE, Z., GAO, F., SHA, T., HU, Y., HE, C. 2009. Isolation and characterization of a $\mathrm{Cr}(\mathrm{VI})$-reduction Ochrobactrum sp. strain CSCr-3 from chromium landfill. $\begin{array}{llll}\text { Journal of Hazardous } & \text { Material, } & \text { 163, } & \text { 869-873. }\end{array}$ http://dx.doi.org/10.1016/j.jhazmat.2008.07.041

IBRAHIM, A.S.S., EL-TAYEB, M.A., ELBADAWI, Y.B., AL-SALAMAH, A.A. 2011. Bioreduction of $\mathrm{Cr}$ (VI) by potent novel chromate resistant alkaliphilic Bacillus sp. strain KSUCr5 isolated from hypersaline Soda lakes. African Journal of Biotechnology, 10, 7207-7218.

IBRAHIM, A.S.S., EL-TAYEB, M.A., ELBADAWI, Y.B., AL-SALAMAH, A.A. 2011. Isolation and characterization of novel potent $\mathrm{Cr}(\mathrm{VI})$ reducing alkaliphilic Amphibacillus sp. KSUCr3 from hypersaline soda lakes. Electronic Journal of Biotechnology, 14(4), 1-14. http://dx.doi.org/10.2225/vol14-issue4fulltext-4 
MABROUK, M.E.M. 2008. Statistical optimization of medium components for chromate reduction by halophilic Streptomyces sp. MS-2. African Journal of Biotechnology, 2, 103-109.

MCLEAN, J., BEVERIDGE, T.J. 2001. Chromate reduction by a Pseudomonad isolated from a site contaminated with chromated copper arsenate. Applied and $\begin{array}{lll}\text { Environmental } \quad \text { Microbiology, } & \text { 67, } & \text { 1076-1084 }\end{array}$ http://dx.doi.org/10.1128/aem.67.3.1076-1084.2001

MEGHARAJ, M., AVUDAINAYAGAM, S., NAIDU, R. 2003. Toxicity of hexavalent chromium and its reduction by bacteria isolated from soil contaminated with tannery waste. Current Microbiology, 47, 51-54 http://dx.doi.org/10.1007/s00284-002-3889-0

MOLOKWANE, P.E., MELI, C.K., EVANS, CHIRWA, M.N. 2008. Chromium

(VI) reduction in activated sludge bacteria exposed to high chromium loading: Brits culture (South Africa). Water Research, 42, 4538-4548. http://dx.doi.org/10.1016/j.watres.2008.07.040

PAL, A., PAUL, A.K. 2004. Aerobic chromate reduction by chromium-resistant bacteria isolated from serpentine soil. Microbiological Research, 159, 347-354 http://dx.doi.org/10.1016/j.micres.2004.08.001

PARK, C.H., KEYHAN, B., WIELINGA, B., FENDORF, S., MATIN, A. 2000 Purification to homogeneity and characterization of a novel Pseudomonas putida chromate reductase. Applied and Environmental Microbiology, 66, 1788-1795. http://dx.doi.org/10.1128/aem.66.5.1788-1795.2000

PATTANAPIPITPAISAL, P., BROWN, N.L., MACASKIE, L.E. 2001. Chromate reduction by Microbacterium liquefaciens immobilized in polyvinyl alcohol. Biotechnology Letters, 23, 61-65.

RAI, D., SASS, B.M., MOORE, D.A. 1987. Chromium (III) hydrolysis constants and solubility of chromium (III) hydroxide. Inorganic Chemistry, 26, 345-349. http://dx.doi.org/10.1021/ic00250a002

SHEN, H., WANG, Y.T. 1995. Modelling simultaneous hexavalent chromium reduction and phenol degradation by a defined coculture of bacteria Biotechnology and Bioengineering, 6, 606-613. http://dx.doi.org/10.1002/bit.260480608

SULTAN, S., HASNAIN, S. 2006. Characterization of an Ochrobactrum intermedium strain STCr-5 manifesting high level $\mathrm{Cr}(\mathrm{VI})$ resistance and reduction potential. Enzyme Microbial Technology, 39, 883-888. http://dx.doi.org/10.1016/j.enzmictec.2006.01.019

SULTAN, S., HASNAIN, S. 2007. Reduction of toxic hexavalent chromium by Ochrobactrum intermedium strain SDCr-5 stimulated by heavy metals. $\begin{array}{llll}\text { Bioresource } & \text { Technology, } & \text { 98, } & 340-344\end{array}$ http://dx.doi.org/10.1016/i.biortech.2005.12.025

THACKER, U., PARIKH, R., SHOUCHE, Y., MADAMWAR, D. 2007. Reduction of chromate by cell-free extract of Brucella sp. isolated from $\mathrm{Cr}(\mathrm{VI})$ contaminated sites. Bioresource Technology, 98, 1541-1547. http://dx.doi.org/10.1016/j.biortech.2006.06.011

WANG, Y.T., XIAO, C. 1995. Factors affecting hexavalent chromium reduction in pure cultures of bacteria. Water Research, 29, 2467-2474. http://dx.doi.org/10.1016/0043-1354(95)00093-Z

WANI, R., KODAM, K.M., GAWAI, K.R., DHAKEPHALKAR, P.K. 2007. Chromate reduction by Burkholderia cepacia MCMB-821 isolated from the pristine habitat of alkaline crater lake. Applied Microbiology and Biotechnology, 75, 627-632. http://dx.doi.org/10.1007/s00253-007-0862-7 